\title{
R-peaks detection method for classifying arrhythmia disorder
}

\author{
Anggit Ferdita Nugraha*, Brahmantya Aji Pramudita, Noor Akhmad Setiawan, Hanung \\ Adi Nugroho \\ Department of Electrical Engineering and Information Technology, Faculty of Engineering, \\ Universitas Gadjah Mada, Yogyakarta
}

DOI: http://dx.doi.org/10.19106/JMedSci004904201705

\section{ABSTRACT}

Electrocardiography (ECG) is a non-invasive technique that is used to diagnose heart abnormalities. ECG records all heart activities and represent them using bio electric signals. Arrhythmia is one of the cardiac disorder that can be detected using ECG. Arrhythmia need to be detected early because of an early symptom of heart disease as deadly as coronary heart disease and heart failure. Arrhythmia described using the difference between the R-peaks based on QRS complex. Therefore, R-peaks detection will be an important factor that can be used to classify arrhythmia disease. One of the widely used methods to detect R-peaks is Pan-Tompkins method. Pan-Tompkins method used a threshold value approach to get all location of R-peaks point from the ECG signals. This study proposed a development based on Pan-Tompkins method by change the threshold value using normalize technique and moving windows approach to get all location of R-peaks point from the ECG signals. This study uses MIT-BIH arrhythmia dataset. This method can show the R-peaks detection with $99.83 \%$ sensitivity and $0.40 \%$ total error rate detection. Hence, this method has potential to be used for classifying arrhythmia disorder based on the R-peaks point.

\section{ABSTRAK}

Elektrokardiografi (ECG) merupakan salah satu metode non-invasif yang digunakan untuk membantu mendiagnosis berbagai kelainan jantung. ECG bekerja dengan merekam berbagai aktivitas jantung dan merepresentasikannya ke dalam bentuk isyarat listrik jantung. Aritmia merupakan salah satu kelaian jantung yang mampu di deteksi menggunakan ECG. Aritmia perlu dideteksi secara dini karena merupakan awal gejala terjadinya penyakit jantung yang mematikan seperti jantung koroner dan gagal jantung. Adanya aritmia pada isyarat ECG digambarkan dengan selisih jarak antar puncak $\mathrm{R}$ berdasarkan kompleks QRS. Sehingga titik puncak $\mathrm{R}$ menjadi salah satu factor penting yang dapat digunakan untuk mengkalasifikasi adanya aritmia. Metode Pan-Tompkins menjadi metode yang paling banyak digunakan pada penelitian untuk menentukan titik puncak $R$ pada isyarat ECG. Metode Pan-Tompkins menggunakan pendekatan nilai ambang untuk menemukan adanya titik puncak pada isyarat ECG. Pada penelitian ini diusulkan pengembangan suatu metode berdasarkan metode Pan-Tompkins dengan mengubah nilai ambang menggunakan teknik normalisasi serta menambahkan pendekatan moving window untuk mendapatkan titik puncak pada isyarat ECG. Pengembangan metode ini diimplementasikan menggunakan dataset MIT-BIH aritmia dengan nilai sensitivitas yang dihasilkan sebesar $99.83 \%$ dengan rata-rata kesalahan deteksi $0.40 \%$. Berdasarkan hasil tersebut dapat disimpulkan metode 
ini mempunyai potensi baik untuk mendeteksi adanya titik puncak pada isyarat ECG yang mendukung klasifikasi aritmia.

Keywords: electrocardiography - R-peaks detection - QRS complex - arrhythmia disorder - Pan-Tompkins method

\section{INTRODUCTION}

Heart is the most important part of human circulatory system. ${ }^{1-3}$ Heart has two main functionality, the first one is to circulate oxygen and nutrients throughout the body, and the second one is to carry away the remains of the metabolism. ${ }^{4}$ Heart has also affect the performance of the other parts, hence cardiac disorder will cause disruption of the entire performance of system in the human body. ${ }^{5}$

World Health Organization (WHO) states that heart disease is the leading cause of death in the worldwide. Around 17.3 million people worldwide die from heart disease annually and it was predicted to grow to 23.6 million in 2030. ${ }^{1,3}$ Therefore, early detection become solution to reduce the number of deaths cause of cardiac disease. ${ }^{6}$ Electrocardiography (ECG) can be used for early detection of cardiac disorder. ECG is a medical instrument that is used to monitor heart activities. ECG uses electrodes on the limb or chest to record all activities and represent it using bio electric signals. ${ }^{7}$ A normal rhythm on an ECG signal consist P-QRS-T wave as shown in the FIGURE $1.6,8,9$

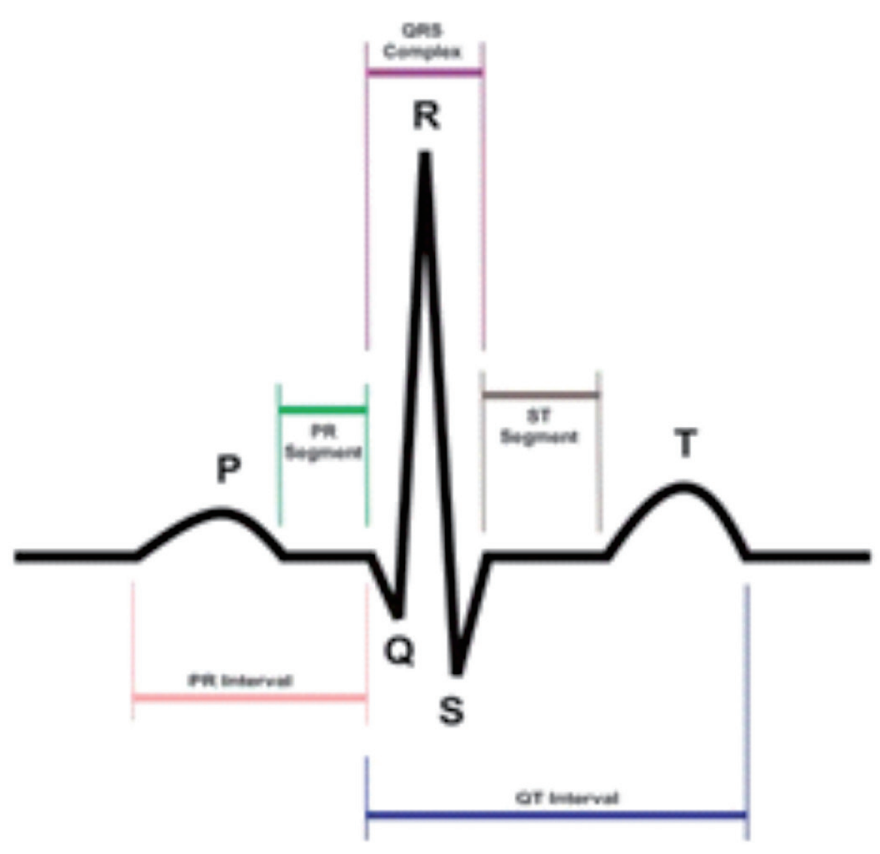

FIGURE 1. ECG Waveform 
QRS wave or QRS complex has an important role for ECG analysis. ${ }^{10-14}$ beat segments, or any other morphological parameters of electrocardiogram (ECG Characteristic of QRS complex based on the rhythmic of depolarization and repolarization of atria and ventricles. ${ }^{15}$ Therefore it provides information about current state of the heart. ${ }^{16}$ Arrhythmia is one of the heart abnormalities that can be determined by the QRS complex waveform. Arrhythmia need to be detected early because of an early symptom of heart disease as deadly as coronary heart disease and heart failure. Arrhythmia described using the difference between the R-peaks based on QRS complex. Therefore, R-peaks detection will be an important factor that can be used to classify arrhythmia disease.

Many algorithm for ECG signal analysis especially for R-peaks detection has been proposed by many researches to increase the accuracy of the system. One of this algorithm is Pan-Tompkins method. Pan-Tompkins method emphasizes on a derivative-based approach to get R-peaks on ECG signal. ${ }^{9}$ The result of that method is $98 \%$ accuracy. In this study, we proposed a development method based on Pan-Tompkins algorithm. This method has the same process like filtering process, squaring and derivative-based approach from Pan-Tompkins method, but we adjusted the threshold for R-peaks detection with normalization technique and moving window approach. By adjusting the process, we expected the sensitivity for detecting R-peaks on ECG signal can be increased.

\section{MATERIALS AND METHODS}

This study conduct in several steps as shown as in FIGURE 2. Data acquisition, filter process, derivation process, squaring process, and peak detection were the step that must be done to get all location of the R-peaks points from the ECG signal. Explanation of each process would be explained further on each subsection.

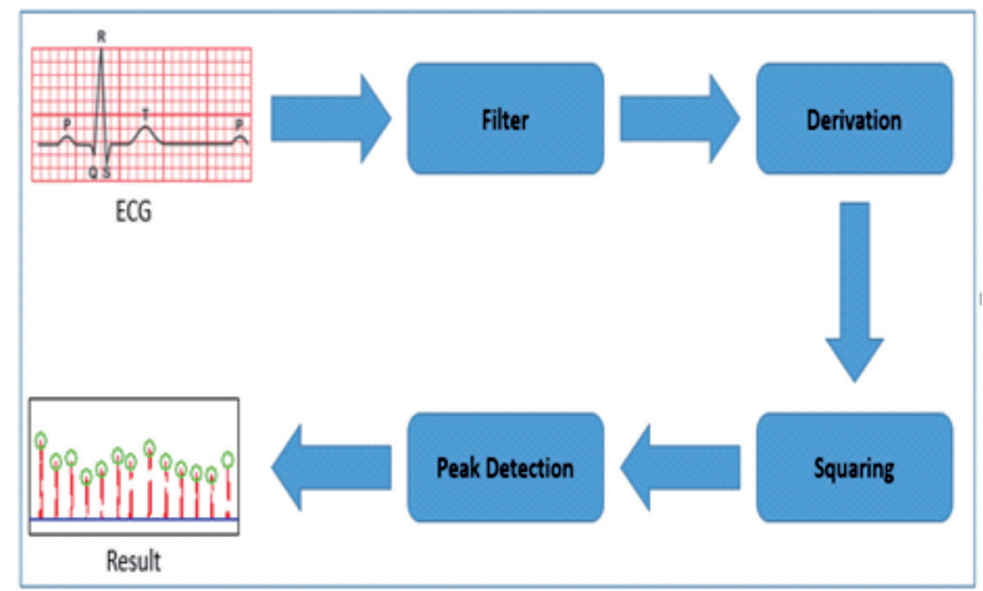

FIGURE 2. R-peaks detection method 


\section{Data acquisition}

Data acquisition is the initial process, therefore this step must be done first. Data acquisition is the process to gather many data that is used to analysis process. ${ }^{15}$ In this study we used MIT-BIH arrhythmia dataset from Physionet. ${ }^{17}$ Thus dataset consisted of 48 record with 15 records contain arrhythmia clinical phenomena and the rest was contain record from normal volunteers. Duration for each record from this dataset was 30 minutes include modified limb lead II (MLII) and the modified lead V1, V2, V4, or V5.

\section{Filtering process}

Filter is a process that is used to remove some unwanted feature from a signal ${ }^{15}$. In this case, filter would be used to remove baseline wander, muscular activity, and interference signal from the other nearby device that existed in this dataset that we gathered from data acquisition.

We applied band pass filter to attenuate noise and maximize the QRS energy. In many references, frequency that contain QRS energy is approximately 5-12 Hz. ${ }^{9,18}$ Band pass filter process for this study composed by cascade high-pass filter and low-pass filter based on Pan-Tompkins method.

Low-pass filter that implemented in this study was $2^{\text {nd }}$ order low-pass filter with $11 \mathrm{~Hz}$ cut-off frequency and the gain was 36 . The transfer function for this low-pass filter was:

$$
H(z)=\frac{\left(1-z^{-6}\right)^{2}}{\left(1-z^{-1}\right)^{2}}
$$

This was the different equation for low-pass filter after user transfer function:

$$
y[n T]=2 y[n T-T]-y[n T-2 T]+x[n T]-2 x[n T-6 T]+x[n T-12 T] .
$$

High pass filter designed for subtracting the output of low-pass filter. This design used $5 \mathrm{~Hz}$ for low frequency and 32 for the filter

gain. Therefore, the transfer function for that design was:

$$
H(z)=\frac{\left(1+32 z^{-16}+z^{-16}\right)}{\left(1+z^{-1}\right)}
$$

This was the different function based on the high-pass transfer function:

$$
y[n T]=32 x[n T-16 T]-y[n T-T]+x[n T]-x[n T-32 T] .
$$

The result of the filtering process used for the next process.

\section{Derivation process}

Derivation or derivative filter is the process after filtering signal to provide the slope information of QRS complex. ${ }^{9}$ PanTompkins method use five-point derivative that shown good enough information of slope to get QRS complex.

Five-point derivative filter used this equation for the transfer function:

$$
H(z)=\left(\frac{1}{8}\right) T-\left(-z^{-2}-2 z^{-1}+2 z+z^{2}\right) .
$$


After apply that transfer function, the different equation for derivative filter was:

$$
y[n T]=\left(\frac{1}{8} T\right)-x[n T-2 T]-2 x[n T-T]+2 x[n T+T]+x[n T+2 T] .
$$

The result of this equation could be said as the ideal model to know the QRS information.

\section{Squaring process}

Squaring function applied for the output of derivative filter. The equation for squaring function was:

$$
y[n T]=(x[n T])^{2}
$$

This function made all data point's positive and emphasizing the higher frequency because of derivative filter. Hence, it would be easier to determine the R-Peaks.

\section{R-peak detection}

R-peaks could be known as the highest point from QRS complex. To determine many points as R-peaks, first we implemented normalized pattern technique for manipulate all data points under the threshold as a zero points. The threshold obtained by twice of the average value of all data points. The threshold was used to separate every signal that contain QRS complex based on time domain.
Every point from each signal that contained of QRS complex would be compared point by point using moving window method. The highest one would be saved as R-peaks. FIGURE 3 shows the output from every process that conducted by this proposed method. FIGURE 3a shows the raw ECG data record 100 that is used to detect all R-peaks point. The first process was used to filter process in order to remove noise and unwanted feature. The result of this process is shown in FIGURE 3b. The output from filtering process was used for derivation function to get information slope of QRS complex.

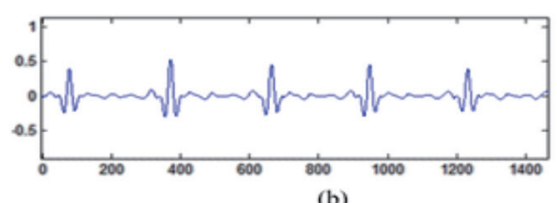

(b)

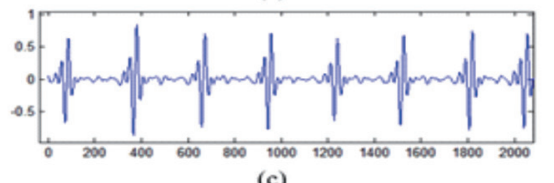

(c)

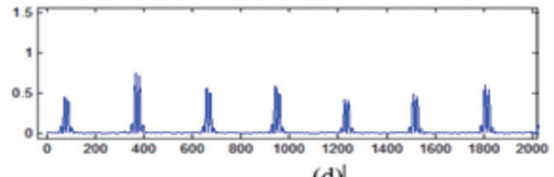

(d)

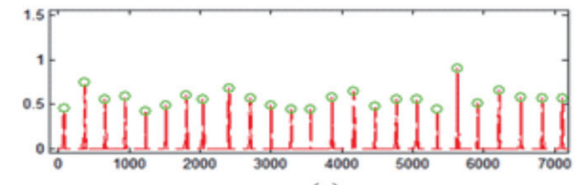

(e)

FIGURE 3. Step by step output of R-peak detection method. a. raw ECG record 100; b. output filtering process record 100; c. output derivative filter record 100; d. output squaring function record 100; e. R-peak location based on the method. 
The result of derivation process is shown as FIGURE 3c, whereas FIGURE 3d shows the all positive data based on the output of derivation filter. This function used to know the dominant feature to get R-peaks point. After implemented the normalization technique and moving windows approach, all R-peaks point would be detected as the result that shown in FIGURE 3e.

\section{RESULTS}

This study has been trained and tested with MIT-BIH Arrhythmia dataset. The performance of this proposed method was evaluated using sensitivity and total detection error. The sensitivity parameter used to evaluate how precise the result of the system compare with the value that detected as R-peaks. The other hand, total detection error used to evaluate how big a system error in detecting the R-peak in each record.

The Sensitivity (Se) of the proposed method was calculated using this function:

$$
S e=\frac{T P}{T P+F N}
$$

And the total error detection (Err) was defined as:

$$
\text { Err }=\frac{F P+F N}{\text { Total No.of } R-\text { Peaks }} * 100
$$

True Positive (TP), False Positive (FP), and False Positive (FN) were main criteria to determine the value of the accuracy and total error detection. TP was obtained from the number of R-peaks that detected from the system based on the ground truth. FP contained the number of points that detected by the system but in the ground truth that point was not the R-peaks. Last, FN was the number of points that was not detected by the system and it's the R-peaks based on the ground truth
TABLE 1. Performance result of R-peaks detection dataset MIT-BIH arrhythmia

\begin{tabular}{cccccc}
\hline Rec & Se & Err & Rec & Se & Err \\
\hline 100 & 100 & 0.00 & 201 & 100 & 0.00 \\
101 & 100 & 0.00 & 202 & 100 & 0.00 \\
102 & 100 & 0.00 & 203 & 100 & 2.00 \\
103 & 100 & 0.00 & 205 & 100 & 0.00 \\
104 & 100 & 0.00 & 207 & 100 & 1.20 \\
105 & 100 & 0.00 & 208 & 100 & 1.92 \\
106 & 100 & 0.00 & 209 & 100 & 0.00 \\
107 & 100 & 0.00 & 210 & 100 & 1.10 \\
108 & 100 & 0.00 & 212 & 100 & 0.00 \\
109 & 100 & 0.00 & 213 & 100 & 0.00 \\
111 & 100 & 0.00 & 214 & 100 & 0.00 \\
112 & 100 & 0.00 & 215 & 100 & 0.00 \\
113 & 100 & 0.00 & 217 & 100 & 0.00 \\
114 & 100 & 0.00 & 219 & 100 & 0.00 \\
115 & 100 & 0.00 & 220 & 100 & 0.00 \\
116 & 100 & 0.00 & 221 & 100 & 0.00 \\
117 & 100 & 0.00 & 222 & 100 & 0.00 \\
118 & 100 & 0.00 & 223 & 100 & 0.00 \\
119 & 100 & 0.00 & 228 & 100 & 4.00 \\
121 & 100 & 0.00 & 230 & 100 & 0.00 \\
122 & 100 & 0.00 & 231 & 100 & 0.00 \\
123 & 100 & 0.00 & 232 & 91.94 & 8.77 \\
124 & 100 & 0.00 & 233 & 100 & 0.00 \\
200 & 100 & 0.00 & 234 & 100 & 0.00 \\
\hline Average & & & & 99.83 & 0.40 \\
\hline & & & & & \\
119 & 100
\end{tabular}

TABLE. 1 summarizes the result for the R-peaks detection based on the proposed method that we applied. The result showed that the average of sensitivity parameter was $99.83 \%$ with average for error detection was 0.40 . From that result, only record 232 that contained many error on the experiment especially for sensitivity evaluation. This error occurred because there were many point on record 232 had an upper value than the threshold because of the filtering process. Hence, that point would be considered as QRS complex because by using squaring function as transformation method. 


\section{DISCUSSION}

Several studies have suggested that QRS complex is an important feature that support various classification process especially for ECG classification. Sathyapriya et al. ${ }^{18}$ reported QRS detection using Pan-Tompkins method with band pass filter to reduce the noise of raw data. The result showed that the classification's accuracy of normal and abnormal heart beat increased more than 90\%. The other study using QRS complex to detect R-peaks point was reported by Bawa \& Sabherwal. ${ }^{19}$ This study explained R-peaks from the QRS complex that detected using modified Pan-Tompkins method. Thresholding was applied as modified method to reduce computation process for detecting all R-peaks location. The result showed that all detected R-point might support many process of arrhythmia classification based on RR interval method.

Our study focused on how to develop the method that used to determine the location of R-peaks points based on the QRS complex. The R-peaks point will be an important feature to classify cardiac disease especially arrhythmia disease. As the method is getting more sensitive to get the feature, the more accurate arrhythmia disorder can be classified from ECG signal

Based on the experiment, our method has been developed using several steps that explained at the materials and method section. This section explained the step by step how to proceed the data set until get the R-peaks point from each record. First process was to gather data from MIT-BIH arrhythmia data set. All record from this data set would be used for the next process to get the R-peaks point from the ECG signal. Every record had to be filtered at the next process used filtering process. Filtering process was used to remove some unwanted feature that affected result of the R-peaks detection. After filtering process, we used derivation filter to make a normalize wave form that was used to provide the slope information of QRS complex. The output from the derivation process would be used for the squaring process. This process was used to transform the data into positive value, hence it would be easier to determine the location of R-peaks point.

Performance evaluation system from the experiments used sensitivity parameter and total error detection. Sensitivity parameter could be calculated using evaluation parameter such as true positive, false positive, and false negative. True negative was not used to this evaluation because the system focused on the R-peaks. Hence, the other points that not R-peaks would not save by the system. Based on the experiment's result, this method has potential to detect all R-points as features for classifying cardiac disorder especially arrhythmia.

\section{CONCLUSION}

R-peaks become dominant features in classifying cardiac disease especially arrhythmia. The more sensitive method that is used to R-peaks detection, more precious classification result in arrhythmia disorder. Our proposed method uses the development method based on Pan-Tompkins method. This development method adjusts the threshold value by normalization technique and moving windows approach to get the R-peaks from the QRS complex waveform. Based on the experiment using MIT-BIH arrhythmia dataset, this method showed the high sensitivity to detecting all R-peaks location from ECG waveform. Hence, this method has potential to detect all R-Points as an important feature to classifying arrhythmia disease. 


\section{ACKNOWLEDGEMENTS}

We would like to thank our colleagues from Department of Electrical Engineering and Information Technology, Faculty of Engineering, Universitas Gadjah Mada, Yogyakarta who have supported this study.

\section{REFERENCES}

1. Mozaffarian D, Benjamin EJ, Go AS, Arnett DK, Blaha MJ, Cushman M, et al. Executive Summary: Heart Disease and Stroke Statistics-2015 Update. A Report from the American Heart Association. AHA Statistical Update. January 26, 2015. https:// doi.org/10.1161/CIR.0000000000000157

2. Rai HM, Trivedi A, Shukla S, Dubey V. ECG arrhythmia classification using daubechies wavelet and radial basis function neural network. 3rd Nirma Univ Int Conf Eng NUiCONE 2012. 2012; 6-8. https://doi. org/10.1109/NUICONE.2012.6493281

3. Fitria D, Ma'sum MA, Imah EM, Gunawan AA. Automatic arrhythmias detection using various types of artificial. J Comput Sci Inf 2014; 90-100.

4. Park J, Lee K, Kang K. Arrhythmia detection from heartbeat using k-nearest neighbor classifier. Proc 2013 IEEE Int Conf Bioinforma Biomed. IEEE BIBM 2013; 15-22. https:// doi.org/10.1109/BIBM.2013.6732594

5. Pingale SL. Using Pan Tompkin ' S Method, ECG signal processing and dignose various diseases in Matlab. Proc IRF Int Conf; 57-61, Pune, India 2014.

6. Boonperm P, Supakasemwong D, Naiyanetr P. ECG analyzing program for arrhythmia detection. BMEiCON $2014-7^{\text {th }}$ Biomed Eng Int Conf 2015; 4-7.

7. Patel AM, Gakare PK, Cheeran AN. Real time ECG feature extraction and arrhythmia detection on a mobile platform. Int J Comput Appl 2012; 44:40-45.
8. Yazdani S \& Vesin JM. Extraction of QRS fiducial points from the ECG using adaptive mathematical morphology. Digit Signal Process A Rev J 2016; 56: 100-109.

9. Pan J \& Tompkins WJ. A real-time QRS detection algorithm. IEEE Trans Bio-medical Eng Eng BME 1985; 32: 230-6. https://doi. org/10.1109/TBME.1985.325532

10. Sharma LD \& Sunkaria RK. A robust QRS detection using novel pre-processing techniques and kurtosis based enhanced efficiency. Meas J Int Meas Confed 2016; 37: 194-204. https://doi.org/10.1016/j. measurement.2016.03.015

11. Elgendi M, Eskofier B, Dokos S, Abbott D. Revisiting QRS detection methodologies for portable, wearable, battery-operated, and wireless ECG systems. PLoS One 2014; https://doi.org/10.1371/journal.pone.0084018

12. Zhang H. An improved QRS wave group detection algorithm and Matlab implementation. Phys Procedia 2012; 25:1010-6. https://doi.org/10.1016/j.phpro. 2012.03.192

13. Álvarez RA, Penín AJM, Sobrino XAV. A comparison of three QRS detection algorithms over a public database. Procedia Technol 2013; 9:1159-65. https://doi.org/10.1016/ j.protcy.2013.12.129

14. Sadhukhan D \& Mitra M. R-peak detection algorithm for ECG using double difference and RR interval processing. Procedia Technol 2012； 4: 873-7. https://doi.org/10.1016/ j.protcy.2012.05.143

15. Saini I, Singh D, Khosla, A. QRS detection using K-Nearest Neighbor algorithm (KNN) and evaluation on standard ECG databases. J Adv Res 2013; 4: 331-44. https://doi. org/10.1016/j.jare.2012.05.007

16. Zidelmal Z, Amirou A, Adnane M, Belouchrani A. QRS detection based on wavelet coefficients. Comput Methods 
Programs Biomed 2012; 107: 490-6. https:// doi.org/10.1016/j.cmpb.2011.12.004

17. MIT-BIH Arrhythmia Database. www. physionet.org/physiobank/database /mitdb

18. Sathyapriya L, Murali L, Manigandan $T$. Analysis and detection R-peak detection using Modified Pan-Tompkins algorithm.
Proc 2014 IEEE Int Conf Adv Commun Control Comput Technol ICACCCT 2014 2015; 483-7.

19. Bawa K \& Sabherwal P. R-peak detection by modified Pan-Tompkins algorithm. Int J Adv Res Technol 2014; 3(5):30-3. 